\title{
US Trade and Access to Trade Facilitating Services in Partner Countries : An Empirical Analysis
}

\author{
Richard J. Cebula \\ Jacksonville University \\ Joy Mazumdar \\ Usha Nair-Reichert \\ Georgia institute of Technologe
}

\begin{abstract}
The issue of liberalization of international trade in services has received considerable attention in recent years. One of the benefits discussed in the literature is the role of services in facilitating goods trade among countries. We test this claim by analyzing the impact of trade in services on manufactured goods exports to the U.S. using data for 30 trading partners for the period 1992-2000. We use Instrumental Variable estimation to control for potential endogeniety. Our analysis also addresses the debates regarding whether services trade and goods trade are substitutes or complements. The answer depends upon whether imported services are used more intensively in the traded goods sector or in the non-traded goods sector. The key empirical results indicate that, on average, aggregate service imports from the U.S. have a significant and positive impact on goods exports to the U.S. in the case of low income nations but not in the case of high income countries. In most cases, the impact is significant and positive for business

\footnotetext{
*Corresponding address: Richard J. Cebula; Jacksonville University, Davis College of Business Jacksonville, FL 32211, Tel: 912-656-2997, Fax: 904-256-7467, E-mail: rcebula@ju.edu. / Usha NairReichert; School of Economics, Georgia Insitute of Technology Atlanta, GA 30332-0615, Tel: 404-8944903, Fax: 404-894-1890, E-mail: usha.nair@gatech.edu.

(c)2011-Center for Economic Integration, Sejong Institution, Sejong University, All Rights Reserved.
} 
services, while it is negative and statistically significant in the case of financial services. The latter outcome could be due to a Rybczynski type effect if financial services are used mostly in sectors that do not export to the U.S.

- JEL Classification: F11, F13, F20

- Keywords: Export Competitiveness, Service Trade, Goods Trade

\section{Introduction}

Liberalization of trade in services has been an ongoing part of the World Trade Organization's agenda in recent years under the auspices of the General Agreement on Trade in Services (GATS). Producer services such as transportation, telecommunications, management consulting, engineering consulting, banking, insurance, marketing and financial services have all become increasingly important both in their role in the domestic economy and in international trade. Liberalization of trade in services was included as part of the WTO agenda based on the expectation that increased trade in services will lead to significant welfare gains. These gains are expected to arise because services provide essential inputs and also satisfy consumption directly. ${ }^{1}$

There are numerous illustrations of the role of foreign services in facilitating trade in goods. DHL's Worldwide Medical Express (WMX) logistics services for the pharmaceutical and life sciences industries in India provides a single window that takes encompasses everything from packaging, documentation, en route tracking of shipments, and proof that under distribution conditions the consignments have remained within defined temperature limits. ${ }^{2}$ Dunn $\&$ Bradstreet's (D\&B) Export Marketing Solutions help foreign firms find overseas buyers for their products and services. ${ }^{3}$ The quantitative literature using CGE modeling finds some evidence that liberalization of trade in services has a large impact on exports (Robinson, et al. (1999). ${ }^{4}$

\footnotetext{
${ }^{1}$ The various types of barriers to service trade are listed in Table 1.

${ }^{2}$ http://www.dhl.co.in/publish/etc/medialib/g0/downloads/sector.Par.0005.File.tmp/dhl_fashion.pdf http:/ /www.dhl.co.in/publish/in/en/press/press/2004_pr/wmx_india.high.html.

${ }^{3}$ http://www.dnb.co.in/ExpMktSolution.htm http://www.dnbasia.com/cn/english/services/credit/ prod_cx.asp.

${ }^{4}$ The literature on the impact of service trade consists of CGE models to estimate the impact of service trade liberalization (Brown Deardorff and Stern (2002), Dee and Hanslow (2000) Robinson, Wang and Martin (1999)) and some econometric work relating service trade liberalization to growth ((Matoo, Rathindran and Subramaniam (2001), Francois and Schuknecht (1999)); see Whalley (2003) for a survey.
} 
This study examines whether service trade contributes to increased trade in goods. One argument put forth for liberalizing service trade is that service imports may be necessary, especially for developing countries, to enhance their international competitiveness and boost exports (Hoekman and Braga, (1997); OECD, 2002). Markusen et al. (2000) note that “..imported services may provide crucial missing inputs which allow a country to produce and export goods in which the country has a natural comparative advantage except for the missing input. This has the potential for huge surplus value. The Arabian Gulf may have had huge oil supplies, but expertise was required to bring it to market. A few hundred million dollars worth of foreign expertise likely had a return of many billions of dollars." 5

There are several possible mechanisms through which service imports could facilitate exports. Imported services could be an input into production (Jones and Ruane, 1990; Hirsch, 1989; Melvin, 1989; Burgess, 1990; Djajic and Kierskowski, 1989; Markusen, 1989; Francois, 1990; Ishikawa, 1992; Marrewijck et el., 1996, 1997; Markusen, et al., 2000). Service imports could also reduce transportation costs and therefore increase exports (Deardorff 2000) or facilitate fragmentation of production and hence lead to international outsourcing activities (Jones and Kierzkowski, 1990). Moreover, country-specific services may be needed to export to a nation; for example, U.S. services such as advertising and legal services may be needed to sell to the U.S. market.

Interestingly, the literature suggests that the relationship between service imports and goods trade is, overall, ambiguous. Because services in certain cases can be production inputs, the literature looking at the connection between factor mobility and goods trade (Mundell, 1957; Markusen, 1983; Svennson, 1984; Markusen and Svensson, 1985) is relevant for understanding the relationship between service trade and goods trade. Mundell (1957) observes that trade in factors and trade in goods can be substitutes. However, Markusen (1983) shows how trade in factors and goods can be complements when goods trade is not based on factor endowments. On the other hand, Markusen (1988) shows how free trade in service inputs can make trade in final goods redundant since the final goods price will be equalized across countries.

Mazumdar and Nair-Reichert (2005) consider service imports to be an input in the production of goods. They assume that there are two sectors in the economy.

\footnotetext{
5"Foreign Direct Investment in Services and the Domestic Market for Expertise", http://econ.worldbank.org/ docs/1168.pdf.
} 
The first sector is the tradable goods sector, which consists of goods consumed by the U.S. market (they could also be consumed domestically and by other markets). The second sector is modeled as a non-traded sector because the bulk of the goods that are not sold in the U.S. market is likely to be consumed domestically. Imported services can be used in both sectors.

The traded goods sector is modeled as being monopolistically competitive. ${ }^{6}$ Hence, trade will be due to differentiated goods instead of endowments. In this framework, as Markusen (1983) points out, imports of service inputs can increase exports. They assume that there is no domestic production of services and all services have to be imported and are available at world prices in the absence of any distortions. Their model suggests that that while imports of producer services are expected to stimulate goods exports, this may not occur if the imported services are used mostly in the non-traded sector. This leads to the possibility that service imports may actually decrease goods exports, a conclusion that is contrary to conventional wisdom. This is due to a Rybczynski type effect, which occurs because the expansion of the non-trade sector due to the inflow of services draws resources away from the traded sector and reduces the size of the latter. ${ }^{7}$ Thus, service trade can be either a complement or substitute to goods trade, depending upon whether imported services are used more intensively in the trade good sector or in the non-traded sector.

The key questions addressed in the present study are the following: Do service imports indeed help in increasing manufactured goods exports? Are there certain types of services that facilitate exports more than others? Do service imports have a greater role in facilitating trade in developing countries than in developed countries? Our objective is to determine whether service imports have an impact on exports at the economy-wide level (as opposed to the firm level). We focus on service imports from the U.S. because of data availability considerations. ${ }^{8}$

The main contribution of this study is offering the set of insights regarding the relationship between goods trade and service trade. Our results indicate that, on average, service imports have a significant effect on exports in the case of developing countries but not in the case of industrialized nations. The positive

\footnotetext{
${ }^{6}$ Monopolistic competition models with varieties provide an unambiguous positive relationship between output and exports.

${ }^{7}$ The Rybczynski effect drives the basic result in Mundell as well since factor mobility leads to the expansion of the importable sector and a contraction of the exportable sector.

${ }^{8}$ Since service imports from the US are likely to have a stronger impact on goods exports to the US, if there is indeed a services-exports link, we look at the link between these two variables.
} 
impact is significant in most cases for business services. We do not have sufficient evidence that easier access to telecommunication services significantly helps to facilitate exports. Financial services are consistently negative, and significant in most cases, perhaps because of the Rybczynski type effect that could occur if these services are used mostly in sectors other than manufacturing. Our findings imply that whether or not services trade and goods trade are substitutes or complements depends on the kind of services being considered.

This balance of this study proceeds as follows. Section II discusses estimation issues and the data. Section III presents the empirical results. Finally, Section IV summarizes the key conclusions of the study.

\section{Data and Descriptive Statistics}

The data are assembled from a variety of sources and cover the period from 1992 to 2000. The data on trade flows is from the U.N. trade database complied by Statistics Canada and comprise of the value of exports from each exporter to the U.S. for the period 1992-2000. Only those countries with which there are positive trade flows are included in the data; in other words, if there was a zero trade flow between the U.S. and any partner country, then that observation was excluded from the data. ${ }^{9}$ We use aggregate bilateral goods trade data since the bilateral service trade data are available only at an aggregate level.

The data on service imports from the U.S. were obtained from the Bureau of Economic Analysis. Service trade takes the form of cross-border transactions and also services provided through affiliates. ${ }^{10}$ Services provided through affiliates are

\footnotetext{
${ }^{9}$ Zeros trade flows could occur for a variety of reasons; our data does not permit us to further analyze this; hence we have excluded such observations from our data.

${ }^{10} \mathrm{An}$ important distinction between services and goods is that the provision of certain kinds of services requires the movement of factors that produce that service. This has implications for the different ways services can be supplied and what can constitute a barrier on service trade. The General Agreement on Trade in Services (GATS), which sets the multilateral rules covering trade in services defines four modes of supply: (a) "Cross-border supply" or services supplied from one country to another (eg., phone calls) (b) Consumption abroad or consumers from one country making use of a service abroad (eg., tourism) (c) "Commercial presence" or a company from one country setting up a subsidiary or branch to provide services abroad (eg., a bank from one country with branches abroad) and (d) "Movement of natural persons" or individuals traveling from one country to supply services in another (eg., consultants). Since the last three modes of supply require the movement of either people or capital, any restrictions on the movement of these can constitute a barrier to service trade. The barriers to service trade, therefore, are more numerous and more complex compared to those on goods trade. A whole range of regulatory measures related to domestic and international activities such as licensing requirements, government procurement, foreign investment restrictions and privatization policies may also result in restricting trade in services.
} 
Table 1. Barriers to Trade in Services

\begin{tabular}{ll}
\hline $\begin{array}{l}\text { Quantitative } \\
\text { Restrictions }\end{array}$ & $\begin{array}{l}\text { Quotas, local content and prohibitions against foreign providers of } \\
\text { services such as domestic transportation, legal, insurance and } \\
\text { investment advising services. }\end{array}$ \\
Price-based Instruments & $\begin{array}{l}\text { Visa fees, entry or exit taxes, discriminatory airline landing fees, } \\
\text { and port taxes }\end{array}$ \\
$\begin{array}{l}\text { Licensing or Certification } \\
\text { Requirements }\end{array}$ & $\begin{array}{l}\text { Licensing or certification of foreign service providers, environ- } \\
\text { mental standards, government procurement polices that favor } \\
\text { domestic over foreign providers of services }\end{array}$ \\
$\begin{array}{l}\text { Discriminatory Access to } \\
\text { Distribution and Commu- } \\
\text { nication Systems }\end{array}$ & $\begin{array}{l}\text { Discriminatory access to distribution and communication systems } \\
\text { in sectors such as telecommunications, air transport, advertising, } \\
\text { insurance and dealer networks. }\end{array}$ \\
\hline
\end{tabular}

Source: Hoekman and Braga (1997), Brown and Stern (2000)

not considered international transactions since the affiliate in the foreign country is considered foreign resident. The dataset we use is that on cross-border service transactions, that is, those that occur between U.S. residents and foreign residents. The data, therefore, exclude services provided through U.S. affiliates in foreign countries. Also, cross-border trade can occur within a firm (between a multinational and its affiliates) or between unaffiliated parties. Our data cover cross-border transactions between unaffiliated parties since only disaggregated service data by country were available for this category only. However, transactions

Table 2. High and Low Income Countries in the Sample

\begin{tabular}{cc}
\hline High Income Countries & Low Income Countries \\
\hline Australia & Argentina \\
Belgium & Brazil \\
Canada & Chile \\
France & China \\
Hong Kong, China & India \\
Israel & Indonesia \\
Italy & Korea, Rep. \\
Japan & Malaysia \\
Spain & Mexico \\
Sweden & Philippines \\
Netherlands & South Africa \\
New Zealand & Thailand \\
Norway & United Kingdom \\
Singapore & Venezuela, RB \\
Switzerland & \\
United Kingdom & \\
\hline
\end{tabular}


between unaffiliated parties constitute the major portion of cross-border service trade. Certain services such as telecommunication services are considered to be between unaffiliated parties only so that our data on these services cover all cross-border transactions. We include three main categories of U.S. service exports - business services, telecommunication services, and financial services. We exclude transportation services since they cannot be considered to be inputs in the actual production process. Also, the problem of reverse causality is likely to be more severe in the case of transportation services. We have an unbalanced panel that covers 30 countries for the period 1992-2000. Appendix 1. lists the sources for all the data, whereas Appendix 2. provides definitions of the services included in our analysis.

Table 3a. US Service Exports as \% of US GDP for Selected Years

\begin{tabular}{cccc}
\hline & 1992 & 1996 & 2000 \\
\hline Business Services & 0.11 & 0.11 & 0.15 \\
Finance & 0.04 & 0.06 & 0.11 \\
Telecommunications & 0.03 & 0.03 & 0.04 \\
\hline
\end{tabular}

Table 3b. Exports and Service Imports from US as \% of GDP of Importing Country (average 1992-2000)

\begin{tabular}{lcccc}
\hline Countries & $\begin{array}{c}\text { Exports to US as as } \\
\text { \% of GDP }\end{array}$ & $\begin{array}{c}\text { Business Imports } \\
\text { as \% of GDP }\end{array}$ & $\begin{array}{c}\text { Finance Imports } \\
\text { as \% of GDP }\end{array}$ & $\begin{array}{c}\text { Telecom Imports } \\
\text { as \% of GDP }\end{array}$ \\
\hline High Income & 4.2 & 0.09 & 0.07 & 0.03 \\
Low Income & 3.7 & 0.15 & 0.04 & 0.03 \\
\hline Low Income & & & & \\
Countries & & & & \\
Brazil & 0.93 & 0.07 & 0.04 & 0.02 \\
Argentina & 0.36 & 0.07 & 0.05 & 0.01 \\
South Africa & 1.05 & 0.06 & 0.02 & 0.03 \\
India & 1.43 & 0.03 & 0.008 & 0.02 \\
Venezuela & 1.7 & 0.43 & 0.09 & 0.05 \\
China & 2.6 & 0.06 & 0.005 & 0.01 \\
Korea & 3.09 & 0.1 & 0.03 & 0.03 \\
Chile & 3.1 & 0.18 & 0.09 & 0.05 \\
Indonesia & 3.1 & 0.25 & 0.03 & 0.02 \\
Phillipines & 4.7 & 0.26 & 0.05 & 0.05 \\
Thailand & 5.3 & 0.11 & 0.02 & 0.02 \\
Malaysia & 8.2 & 0.13 & 0.04 & 0.03 \\
Mexico & 12.6 & 0.16 & 0.06 & 0.08 \\
Median & 3.06 & 0.11 & 0.04 & 0.03 \\
\hline
\end{tabular}


Table 2. lists the countries in the sample. Tables $3 \mathrm{a}$. and $3 \mathrm{~b}$ provide information about U.S. service exports. The columns in Table 3a. provide the shares of the different service categories in U.S. GDP (for the three service categories used in our analysis). As one can see, business services are the most important category, followed by financial services and then by telecommunications. The importance of financial services has increased over time.

Table $3 \mathrm{~b}$. shows the importance of various kinds of service imports in the countries in the sample. The top panel of the table shows the mean shares of exports to U.S., and service imports to GDP ratio for importing countries which are categorized into high- and low- income countries. The major difference between low- and high-income nations in terms of the composition of their service imports is that business services are more important for low-income nations while financial services are less important for low-income nations as compared to high-income nations.

The bottom panel in Table 3b. shows the data for individual countries in the low income category since they are more likely to benefit from service imports, as will be confirmed by our regression results. The countries are arranged in ascending order in terms of the mean share of exports to the U.S. to their respective GDPs. The order of countries is intended to reflect to some extent their success in exporting to U.S. The export share will, of course, be influenced by various other factors including the size of country. However, these numbers may still reveal some broad patterns. The regressions, which are discussed in the next section, will allow us to control for other relevant variables. The export shares are reported in the first column of the table. The share of Brazil's exports in GDP is $0.93 \%$, as reported in the first column. The other columns provide the mean shares of imports of different service categories to the size of the GDP. For example, business services account for $0.07 \%$ of Brazil's GDP whereas financial services and telecommunications services account for $0.04 \%$ and $0.02 \%$, respectively.

It is interesting to see whether there is any correlation between imports of certain kinds of services and export performance. Such information could provide clues regarding that services are important for exports. The share of business services in GDP is higher or equal to the median for the low-income sample (reported in the last row) for the three top exporters (Thailand, Malaysia, and Mexico). The share is well below the median for the bottom three exporters (Brazil, Argentina, and South Africa). There does not seem to be a high correlation between exports and financial service imports. The share is equal to or higher than the median for two of the top 
three exporters, with the same being true for the bottom three exporters. For telecommunication services, the share is equal to or higher than the median for two of the top three exporters. It is lower than the median for two of the bottom three exporters. Business services seem to have the strongest correlation with exports, and this conclusion will be supported by the regression results provided later in this study.

\section{Methodology and Results}

\section{A. Methodology}

The framework used for estimating the impact of service imports on goods exports is linked to two strands of empirical literature in international trade. The first such strand relates output to factor endowments (Harrigan, 1995b; Bernstein and Weinstein, 2002). The second strand reflects the large literature on estimating gravity equations that relate exports to output of trading countries. The present study relates exports of the tradable goods sector to country factor endowments. Country endowments are specified as explanatory variables instead of outputs since the study focuses on determinants of output, which includes both factor endowments and services. ${ }^{11}$ In the present framework, service imports are expected to behave like any other input. Contrary to the usual assumption about factor endowments, however, service inputs are endogenous and depend on restrictions on service trade.

Using aggregate data on manufactured goods exports, the estimating equation takes the form

$$
\text { Exports }_{i t}=\alpha_{0 i t}+\beta_{i t} V_{i t}+\eta_{i t} W_{i t}+\varepsilon_{i t}
$$

where $i$, and $t$ denote country $i$ and time period $t$, respectively. The dependent variable is the log of aggregate bilateral goods exports to the U.S. [ Export $\left._{i t}\right]$. $V$ represents a set of explanatory variables that include country specific endowments of the factors of production and service imports expressed as logs. We include all important factors of production that are usually used in the mainstream literature. The factors of production included are capital, high skilled, medium skilled and unskilled labor, and land. We use service imports into a country as our key

\footnotetext{
${ }^{11}$ Harrigan (1996) uses factor endowments as instruments for sectoral output.
} 
explanatory variable since data on prices of services are difficult to obtain. We include three types of service imports in our regressions, namely business, financial, and telecommunication services. As discussed earlier, the expected signs on the coefficients of imported services and other factors of production can be either positive or negative due to Rybczynski effects. The factors and service imports vary across countries and time.

$W$ includes a set of additional controls such as $\log$ of distance, common language, contiguity that are common gravity variables used to explain trade. We also include the lagged share of services in GDP of each country to capture the fact that service imports could be less in a country with a well developed service industry. A larger economy may both export more and import all kinds of goods and services. While we do have factors of production in our regression, this may not capture this case entirely. Hence, we include GDP (in natural log form) in our regression. Also, it is possible that some countries may have high trade shares with the U.S. due to exogenous reasons and therefore they both export and import more of all kinds of goods and services to and from the U.S. Hence, we use the lagged share of U.S. trade in the country's GDP. Year dummies also included to capture changes in the overall international economic conditions that may influence both service and goods exports across time. ${ }^{12}$

We also address the issue of endogeneity associated with the service trade variable since higher exports from a country may lead to higher imports of services. We use instrumental variables (IV) to address the potential endogeneity in our model. Our instruments for service trade are one-year lagged values of service flows and trade/investment restrictions. ${ }^{13}$

\section{B. Empirical results}

Tables 4. through 7 present provide the empirical results regarding the impact of service imports from the U.S. on exports to the U.S. for the countries in our sample, using both Ordinary Least Squares (OLS) and Instrumental Variable (IV)

\footnotetext{
${ }^{12}$ Data limitations preclude us from using country dummies in the analysis We however analyze low and high income countries separately.

${ }^{13}$ We use lagged service imports, and measures of trade restrictions / investment costs as instruments. The investment cost index is from Kellenberg (2005). It ranges from 0-100 with higher values indicating higher costs of investing in that country. It has been calculated from four questions in the World Competitiveness Report regarding ease of establishing cross-border ventures, Intellectual property rights, hiring and firing practices and the justice system.
} 
Table 4. Aggregate Service Imports from US Dependent Variable: Log of Manufactured Goods Exports to the U.S.

\begin{tabular}{|c|c|c|}
\hline & OLS & IV \\
\hline Distance & $\begin{array}{l}0.16^{*} \\
(0.09)\end{array}$ & $\begin{array}{l}0.21 * * \\
(0.10)\end{array}$ \\
\hline Language & $\begin{array}{l}-0.08 \\
(0.07)\end{array}$ & $\begin{array}{c}0.02 \\
(0.08)\end{array}$ \\
\hline Contiguity & $\begin{array}{c}0.28 \\
(0.25)\end{array}$ & $\begin{array}{c}0.59 * * * \\
(0.26)\end{array}$ \\
\hline Capital & $\begin{array}{c}0.12 * * * \\
(0.05)\end{array}$ & $\begin{array}{c}0.17 * * * \\
(0.06)\end{array}$ \\
\hline Land & $\begin{array}{c}-0.09 * * * \\
(0.02)\end{array}$ & $\begin{array}{c}-0.12 * * * \\
(0.03)\end{array}$ \\
\hline High skilled & $\begin{array}{l}-0.01 \\
(0.06)\end{array}$ & $\begin{array}{c}0.04 \\
(0.07)\end{array}$ \\
\hline Medium skilled & $\begin{array}{r}0.16^{* *} \\
(0.08)\end{array}$ & $\begin{array}{c}0.07 \\
(0.12)\end{array}$ \\
\hline Low skilled & $\begin{array}{c}-0.12 * * * \\
(0.04)\end{array}$ & $\begin{array}{c}-0.12 * * * \\
(0.05)\end{array}$ \\
\hline Lagged US trade share & $\begin{array}{c}9.26 * * * \\
(0.08)\end{array}$ & $\begin{array}{c}8.44 * * * \\
(1.04)\end{array}$ \\
\hline GDP & $\begin{array}{c}0.55 * * * \\
(0.11)\end{array}$ & $\begin{array}{c}0.52 * * * \\
(0.14)\end{array}$ \\
\hline Lagged service sector share in GDP & $\begin{array}{c}-0.03 * * * \\
(0.01)\end{array}$ & $\begin{array}{c}-0.03 * * * \\
(0.01)\end{array}$ \\
\hline Aggregate US service exports & $\begin{array}{c}0.31 * * * \\
(0.06)\end{array}$ & $\begin{array}{c}0.35 * * * \\
(0.01)\end{array}$ \\
\hline Constant & $\begin{array}{l}-0.22 \\
(1.21)\end{array}$ & $\begin{array}{l}-0.04 \\
(1.50)\end{array}$ \\
\hline \# of observations & 161 & 122 \\
\hline $\mathrm{R}^{2}$ & 0.93 & - \\
\hline
\end{tabular}

$* * * * *, *$ denote significance at $1 \%, 5 \%$ and $10 \%$ level, respectively.

Standard Errors are within parenthesis; lagged values are one-year lags.

estimation. ${ }^{14}$ Table 4. presents the results for aggregate service imports for both OLS and IV estimations. We find that in the case of both the OLS and IV regressions, aggregate service imports from the U.S. has a positive and highly significant impact on goods exports to the U.S.

Table 5. examines the same regression specification for low- and high-income countries separately, to test whether service imports from the U.S. differ in their

\footnotetext{
${ }^{14} \mathrm{The} \mathrm{R}^{2}$ in the case of all OLS regressions are greater than 0.9. In all cases, the first stage IV estimation $\mathrm{R}^{2}$ were also greater than 0.9 .
} 
Table 5. Aggregate Service Imports from the US - High and Low Income Countries Dependent Variable: Log of Manufactured Goods Exports to the U.S.

\begin{tabular}{lcccc}
\hline & \multicolumn{2}{c}{ Low income } & Countries & \multicolumn{2}{c}{ High Income Countries } \\
\hline & OLS & IV & OLS & IV \\
\hline Language & $-0.72^{* * *}$ & -0.41 & 0.17 & 0.33 \\
& $(0.13)$ & $(0.28)$ & $(0.19)$ & $(0.28)$ \\
Contiguity & 0.28 & 0.39 & $2.33^{* * *}$ & $2.37^{* * *}$ \\
& $(0.22)$ & $(0.31)$ & $(0.82)$ & $(1.00)$ \\
Distance & $-0.75^{* * *}$ & $-0.74^{* * *}$ & $0.45^{* * *}$ & $0.45^{* * *}$ \\
& $(0.14)$ & $(0.24)$ & $(0.13)$ & $(0.17)$ \\
Capital & -0.26 & -0.69 & 0.07 & 0.12 \\
& $(0.20)$ & $(0.46)$ & $(0.07)$ & $(0.08)$ \\
Land & $-0.62^{* * *}$ & $-0.88^{* * *}$ & $-0.28^{* * *}$ & $-0.31^{* * *}$ \\
& $(0.07)$ & $(0.1)$ & $(0.05)$ & $(0.07)$ \\
High skilled & $-0.45^{* * *}$ & $-0.44^{* * *}$ & $0.44^{* * *}$ & $0.57^{* * *}$ \\
& $(0.07)$ & $(0.14)$ & $(0.13)$ & $(0.15)$ \\
Medium skilled & $0.22^{* * *}$ & -0.06 & 0.002 & -0.13 \\
& $(0.07)$ & $(0.2)$ & $(0.30)$ & $(0.35)$ \\
Low skilled & $0.67^{* * *}$ & $1.04^{* * *}$ & $-0.34^{* * *}$ & $-0.32^{* * *}$ \\
& $(0.09)$ & $(0.14)$ & $(0.08)$ & $(0.11)$ \\
Lagged service sector share in GDP & -0.01 & -0.01 & 0.002 & 0.002 \\
& $(0.01)$ & $(0.02)$ & $(0.01)$ & $(0.01)$ \\
Lagged US trade share & $4.76^{* * *}$ & $3.28^{* * *}$ & $5.16^{* * *}$ & $5.07^{* * *}$ \\
& $(1.07)$ & $(1.3)$ & $(1.69)$ & $(2.00)$ \\
GDP & $0.59^{* * *}$ & $0.71^{* * *}$ & $0.93^{* * *}$ & $0.98^{* * *}$ \\
& $(0.18)$ & $(0.30)$ & $(0.23)$ & $(0.26)$ \\
Aggregate US service exports & $0.26^{* *}$ & $0.68^{* *}$ & 0.002 & -0.11 \\
& $(0.13)$ & $(0.35)$ & $(0.10)$ & $(0.16)$ \\
Constant & 16.55 & 20.74 & -4.42 & -4.5 \\
\# of observations & $(2.19)$ & $(3.38)$ & $(1.93)$ & $(2.22)$ \\
$\mathrm{R}^{2}$ & 73 & 51 & 88 & 71 \\
& 0.96 & - & 0.96 & - \\
\hline$* * * *$ d d & 0.96 & &
\end{tabular}

$* * * * * *$ denote significance at $1 \%, 5 \%$ and $10 \%$ level, respectively.

Standard Errors are within parenthesis; lagged values are one-year lags.

impact on low and high-income countries' exports to the U.S. The first two columns show the results for the low-income sample. The next two columns present the results for the high-income group for purposes of comparison. For the low-income sample, contiguity and distance have the expected signs. Common language has the "wrong" sign but is not statistically significant in the IV estimation. Capital and high-skilled labor negatively impact exports to the U.S., as one would expect. Land negatively impacts exports to the U.S., which makes sense since the dependent 
variable includes exports of manufactured goods only. Low-skilled labor positively affects exports, which is consistent with our expectations. The coefficient for medium- skilled labor changes signs between the OLS and IV estimations. The share of services in GDP does not seem have to impact exports significantly. The lagged trade share with the U.S. exercises a positive and statistically significant

Table 6. Disaggregated Service Imports from US Dependent Variable: Log of Manufactured Goods Exports to the U.S.

\begin{tabular}{|c|c|c|}
\hline & OLS & IV \\
\hline Distance & $\begin{array}{c}0.09 \\
(0.09)\end{array}$ & $\begin{array}{l}0.15 \\
(0.11)\end{array}$ \\
\hline Language & $\begin{array}{l}-0.03 \\
(0.08)\end{array}$ & $\begin{array}{c}0.02 \\
(0.10)\end{array}$ \\
\hline Contiguity & $\begin{array}{c}0.27 \\
(0.26)\end{array}$ & $\begin{array}{r}0.95 * * \\
(0.32)\end{array}$ \\
\hline Capital & $\begin{array}{l}0.10 * \\
(0.05)\end{array}$ & $\begin{array}{r}0.14 * * \\
(0.07)\end{array}$ \\
\hline Land & $\begin{array}{c}-0.12 * * * \\
(0.03)\end{array}$ & $\begin{array}{c}-0.11 * * * \\
(0.03)\end{array}$ \\
\hline High skilled & $\begin{array}{l}-0.02 \\
(0.06)\end{array}$ & $\begin{array}{c}0.04 \\
(0.07)\end{array}$ \\
\hline Medium skilled & $\begin{array}{c}0.10 \\
(0.08)\end{array}$ & $\begin{array}{c}0.03 \\
(0.12)\end{array}$ \\
\hline Low skilled & $\begin{array}{c}-0.08 * * \\
(0.04)\end{array}$ & $\begin{array}{c}-0.12 * * \\
(0.05)\end{array}$ \\
\hline Lagged US trade share & $\begin{array}{c}8.86 * * * \\
(0.83)\end{array}$ & $\begin{array}{c}7.05 * * * \\
(1.32)\end{array}$ \\
\hline GDP & $\begin{array}{c}0.56^{* * *} \\
(0.11)\end{array}$ & $\begin{array}{c}0.58 * * * \\
(0.15)\end{array}$ \\
\hline Lagged service sector share in GDP & $\begin{array}{c}-0.02 * * * \\
(0.006)\end{array}$ & $\begin{array}{c}-0.04 * * * \\
(0.01)\end{array}$ \\
\hline Business & $\begin{array}{c}0.40 * * * \\
(0.09)\end{array}$ & $\begin{array}{c}0.34 * * \\
(0.16)\end{array}$ \\
\hline Finance & $\begin{array}{r}-0.15 * \\
(0.08)\end{array}$ & $\begin{array}{c}0.01 \\
(0.16)\end{array}$ \\
\hline Telecom & $\begin{array}{c}0.08 \\
(0.07)\end{array}$ & $\begin{array}{l}-0.03 \\
(0.12)\end{array}$ \\
\hline Constant & $\begin{array}{c}0.52 \\
(1.17)\end{array}$ & $\begin{array}{c}0.97 \\
(1.59)\end{array}$ \\
\hline Number of observations & 161 & 118 \\
\hline $\mathrm{R}^{2}$ & 0.93 & - \\
\hline
\end{tabular}

$* * *, * *,{ }^{*}$ denote significance at $1 \%, 5 \%$ and $10 \%$ level, respectively.

Standard Errors are within parenthesis; lagged values are one-year lags. 
influence on exports to the US, as one would expect. The variable of central interest, service imports from the US, positively affects total exports in both the OLS and IV regressions and is statistically significant at the $5 \%$ level in both cases. The coefficients/elasticities imply that a $10 \%$ increase in service imports would increase goods exports by $2.6 \%$ according to the OLS estimate and by $6.8 \%$ according to the IV estimate.

On the other hand, for the high-income sample, U.S. service imports are statistically insignificant in both the OLS and the IV specifications. This is what one would expect if high-income countries have a well developed service sector and hence do not rely extensively on service imports to boost exports. The results imply that developing countries are dependent on service imports to provide essential inputs whereas industrialized countries are not.

Table 6. provides the results for the disaggregated service categories for all countries, while Table 7. provides the results for the low-income and high-income groups of nations. In Table 6, the OLS results indicate that business services exercise a positive and statistically significant effect on goods exports to the U.S. Financial services have a negative and statistically significant coefficient. The study by Mazumdar and Nair-Reichert (2005) suggests that this outcome could arise if imported financial services were used more intensively in the non-traded sector and led to an expansion of the non-traded sector and a contraction of the traded sector. In the IV regression, business services elasticity remains positive and statistically significant, and financial services, while negative, now become statistically insignificant. Telecom services are insignificant in both cases. We also examine the impact of disaggregated service measures on low- and high-income countries. In the case of the low-income countries, OLS and IV results indicate that business services have positive and statistically significant effect on goods exports. Financial services have a negative and statistically significant effect. Telecommunication services have a positive coefficient, but it is statistically insignificant.

For the high-income sample, none of the estimated elasticities on the service variables, except that for telecommunications, is statistically significant. Financial services have a negative but insignificant coefficient. The telecommunications services coefficient is positive in both OLS and IV estimations but it is statistically significant only in the OLS regression.

The results from the various regressions offer several insights. Service imports in general are more important in terms of providing essential inputs for low- income countries. Access to business services aids exports. Financial services seem to have 
Table 7. Disaggregated Service Imports from US High and Low Income Countries Dependent Variable: Log of Manufactured Goods Exports to the U.S.

\begin{tabular}{|c|c|c|c|c|}
\hline & \multicolumn{2}{|c|}{ Low Income Countries } & \multicolumn{2}{|c|}{ High Income Countries } \\
\hline & OLS & IV & OLS & IV \\
\hline Language & $\begin{array}{c}-0.92 * * * \\
(0.15)\end{array}$ & $\begin{array}{c}-1.59 * * * \\
(0.47)\end{array}$ & $\begin{array}{c}0.14 \\
(0.20)\end{array}$ & $\begin{array}{c}0.78 \\
(0.49)\end{array}$ \\
\hline Contiguity & $\begin{array}{r}0.47^{* *} \\
(0.24)\end{array}$ & $\begin{array}{c}0.97 * * * \\
(0.37)\end{array}$ & $\begin{array}{c}2.62 * * * \\
(0.75)\end{array}$ & $\begin{array}{c}2.88 * * * \\
(1.09)\end{array}$ \\
\hline Distance & $\begin{array}{c}-0.85 * * * \\
(0.14)\end{array}$ & $\begin{array}{l}-0.1 .27 * * * \\
\quad(0.29)\end{array}$ & $\begin{array}{c}0.45 * * * \\
(0.13)\end{array}$ & $\begin{array}{c}0.31 \\
(0.21)\end{array}$ \\
\hline Capital & $\begin{array}{c}-0.34^{* *} \\
(0.20)\end{array}$ & $\begin{array}{c}-0.90 * * * \\
(0.32)\end{array}$ & $\begin{array}{c}0.06 \\
(0.07)\end{array}$ & $\begin{array}{c}-0.0004 \\
(0.12)\end{array}$ \\
\hline Land & $\begin{array}{c}-0.66 * * * \\
(0.06)\end{array}$ & $\begin{array}{c}-0.92 * * * \\
(0.13)\end{array}$ & $\begin{array}{c}-0.29 * * * \\
(0.05)\end{array}$ & $\begin{array}{c}-0.48 * * * \\
(0.14)\end{array}$ \\
\hline High skilled & $\begin{array}{c}-0.43 * * * \\
\quad(0.07)\end{array}$ & $\begin{array}{c}-0.59 * * \\
(0.15)\end{array}$ & $\begin{array}{c}0.38 * * \\
(0.17)\end{array}$ & $\begin{array}{r}0.60 * * \\
(0.26)\end{array}$ \\
\hline Medium skilled & $\begin{array}{l}0.12^{*} \\
(0.07)\end{array}$ & $\begin{array}{c}0.15 \\
(0.19)\end{array}$ & $\begin{array}{c}0.09 \\
(0.29)\end{array}$ & $\begin{array}{c}0.34 \\
(0.44)\end{array}$ \\
\hline Low skilled & $\begin{array}{c}0.72 * * * \\
(0.09)\end{array}$ & $\begin{array}{c}1.12 * * * \\
(0.15)\end{array}$ & $\begin{array}{c}-0.29 * * * \\
(0.10)\end{array}$ & $\begin{array}{l}-0.02 \\
(0.27)\end{array}$ \\
\hline $\begin{array}{l}\text { Lagged service sector } \\
\text { share in GDP }\end{array}$ & $\begin{array}{l}-0.01 \\
(0.01)\end{array}$ & $\begin{array}{l}-0.02 \\
(0.02)\end{array}$ & $\begin{array}{c}0.01 \\
(0.01)\end{array}$ & $\begin{array}{l}0.06 \\
(0.05)\end{array}$ \\
\hline Lagged US trade share & $\begin{array}{c}3.69 * * * \\
(1.19)\end{array}$ & $\begin{array}{l}-0.21 \\
(1.89)\end{array}$ & $\begin{array}{c}4.51 * * * \\
(1.48)\end{array}$ & $\begin{array}{c}4.69 * * \\
(2.22)\end{array}$ \\
\hline GDP & $\begin{array}{c}0.72 * * * \\
(0.19)\end{array}$ & $\begin{array}{c}1.06 * * * \\
(0.34)\end{array}$ & $\begin{array}{c}0.83 * * * \\
(0.23)\end{array}$ & $\begin{array}{l}0.61 * \\
(0.32)\end{array}$ \\
\hline Business & $\begin{array}{c}0.23 * * * \\
(0.09)\end{array}$ & $\begin{array}{c}0.36 * * * \\
(0.14)\end{array}$ & $\begin{array}{c}0.04 \\
(0.17)\end{array}$ & $\begin{array}{c}0.34 \\
(0.59)\end{array}$ \\
\hline Finance & $\begin{array}{c}-0.23 * * * \\
(0.09)\end{array}$ & $\begin{array}{c}-0.71 * * \\
(0.30)\end{array}$ & $\begin{array}{l}-0.13 \\
(0.16)\end{array}$ & $\begin{array}{l}-0.93 \\
(0.83)\end{array}$ \\
\hline Telecom & $\begin{array}{c}0.13 \\
(0.08)\end{array}$ & $\begin{array}{c}0.17 \\
(0.19)\end{array}$ & $\begin{array}{l}0.15^{*} \\
(0.09)\end{array}$ & $\begin{array}{l}0.23 \\
(0.25)\end{array}$ \\
\hline Constant & $\begin{array}{l}18.31 \\
(2.22)\end{array}$ & $\begin{array}{l}26.15 \\
(3.70)\end{array}$ & $\begin{array}{l}-4.17 \\
(2.00)\end{array}$ & $\begin{array}{l}-4.74 \\
(3.36)\end{array}$ \\
\hline Number of observations & 73 & 48 & 88 & 56 \\
\hline $\mathrm{R}^{2}$ & 0.97 & - & 0.96 & - \\
\hline
\end{tabular}

$* * *, * *, *$ denote significance at $1 \%, 5 \%$ and $10 \%$ level, respectively.

Standard Errors are within parenthesis; lagged values are one-year lags.

a negative effect on exports, possibly because they benefit the non-tradable sector more. According to our theory, the impact of a particular kind of service imports on goods exports depends positively on its relative share in the cost of production of the good. The next step in the analysis is to examine whether our results are 
consistent with the cost shares that we actually observe in the data.

The coefficient for the services term depends on its cost share in gross output of the good and the difference between this share and the cost share of this service in other sectors (Mazumdar and Nair-Reichert, 2005). Our results suggest that the business service intensity of goods produced for the U.S. market should not be too different from (or greater than) that of the non-traded sector. Also, the financial services intensity of goods produced for the U.S. market should be smaller than that of the non-traded sector. We can check whether this is actually true. We use the input-output cost shares of the U.S. manufacturing sector to get estimates of service intensity of goods destined for the U.S. market. The assumption here is that goods destined for U.S. consumption are produced using more or less the same technology, irrespective of where they are produced. We use the IO tables of a developing country, India, to obtain the service intensity of goods that belong to the non-traded sector of a developing economy. We use the average cost shares of the entire Indian economy as our cost shares for the "non-traded" sector since the bulk of the output of the Indian economy is not destined for the U.S. market. The categories in the Indian IO table do not match exactly with our three service categories. Consequently, we use categories that come closest to our three kinds of services. The categories we use from the Indian IO table are "other services" for business services, "banking" for financial services, and "communication" for telecommunications services.

The average cost share of business services in U.S. manufacturing is $4 \%$. The corresponding share for entire Indian economy (interpreting other services as business services) is about $3 \%$. This is consistent with our result that business service imports have a positive effect on goods exports to the U.S. The average cost share of financial services in U.S. manufacturing is about $0.7 \%$. The corresponding share for the Indian economy (interpreting banking as the financial sector) is about $2 \%$. This again is consistent with our result that financial service imports are negatively related to goods exports to the U.S.

The telecommunications intensity for U.S. manufacturing and India are $0.3 \%$ and $0.4 \%$, respectively. The small size of the cost share and small difference between the two cost shares could very well explain why the coefficient on telecommunications services is small and statistically insignificant.

We also estimated regressions with the exports to the rest of the world as the 
dependent variable, with service imports from the U.S. and other relevant controls adopted as explanatory variables. ${ }^{15}$ We expect the coefficient on all the service imports variables to be smaller in these regressions. This is because the service imports to the U.S. are more likely to benefit exports to the U.S. more than exports to the rest of the world. Also, the Rybczynski effect would mean that service imports from U.S. could divert resources away from sectors that export to the rest of the world towards sectors that export to the U.S. and thereby reduce exports to the rest of the world. Thus, the coefficients on the service import variables could be negative in these regressions even though they were positive in the regressions involving exports to the U.S. as the dependent variable.

The results are most interesting for the non-OECD sample. We find that aggregate service imports from the U.S. negatively impact exports to the rest of the world in the OLS regressions (although they are positive but statistically insignificant in the IV regressions). When we use the disaggregated services as the explanatory variables, we find business services to be negative and statistically insignificant, financial services to be negative and statistically significant and telecommunication services to be negative and statistically significant. This makes sense since financial services were found to negatively influence exports to the U.S. and telecommunication services were found to weakly influence exports to the U.S. It would be surprising, therefore, if exports to the rest of the world were found to be positively and significantly related to these services. Business services are positive but still insignificant in the IV regressions. Financial and telecommunication services continue to be negative but become insignificant in the IV regressions.

\section{Concluding Remarks}

In recent years, there have been ongoing multilateral negotiations regarding the liberalization of international trade in services such as transportation, management consulting, engineering consulting, banking, insurance, marketing and finance. Apart from the direct gains experienced by the service industries, it has been argued that

\footnotetext{
${ }^{15}$ Results are not reported in detail in the paper but are available from the authors. Language and contiguity were dropped from these regressions. The distance variable was the minimum Great-Circle distance from US, Western Europe and Japan (measured as distance between the capital city and New York, Rotterdam and Tokyo, respectively; see Gallup, Sachs, Mellinger (1999)). The trade to GDP ratio used was the share of overall trade in GDP.
} 
liberalization of service trade may facilitate goods trade among countries.

We empirically analyze the impact of trade in services on manufactured goods trade. If services are used more intensively in the traded sector, then effect of service imports should definitely be positive. If the traded sector uses imported services less intensively as compared to the non-traded sector, then the effect of service imports is ambiguous. It could even be negative if the imported services intensity of the nontraded sector is considerably higher as compared to the traded sector. Our analysis also contributes to the debates over whether service trade and goods trade are substitutes or complements: service trade can be either a compliment or a substitute to goods trade, depending upon whether imported services are used more intensively in the trade good sector or in the non-traded sector.

More specifically, using U.S. data, the empirical results indicate that service imports in general are more important for developing nations as compared to industrialized nations, in terms of providing essential inputs required for either production or for the trading process itself. Access to business services promotes exports to the U.S. Financial services seem to have a negative effect on such exports. This could be because they are used more intensively in the non-traded sector in developing countries.

An important caveat to keep in mind is that these results are based on data on cross-border trade in services only and the analysis does not include services provided through affiliates. The provision of services through affiliates may be particularly important for financial services. So, it is possible that the negative effect of financial services may disappear once we take this mode of service provision into account. One should also keep in mind that financial services import data does not include foreign capital inflow. It is possible, therefore, that the latter is positively correlated with goods exports while the former is not. Our results imply that whether or not service trade and goods trade are complements or substitutes depends on the service category.

Our analysis has important policy implications for trade negotiations. The effects of service imports on welfare can of course be very different from their effects on exports. However, if stimulating exports is the primary objective, then our results indicate that there is indeed a sound justification for liberalizing service trade. On the other hand, our results also indicate that there is a rationale for liberalizing trade in certain kinds of services before others. Trade in business services may yield greater benefits (in the narrow sense of stimulating exports) compared to financial services. 
Received 1 May 2011, Revised 30 May 2011, Accepted 7 June 2011

\section{References}

Bernstein and Weinstein (2002), "Do Endowments Predict the Location of Production? Evidence from National and International Data," Journal of International Economics, 56(1), 55-76

Brown, D., A. Deardorff and R. Stern (2002), " Computational Analysis of goods and services liberalization in the Uruguay Round and the Doha Development Round," Discussion Paper no. 489, Research Seminar in International Economics, School of Public Policy, The University of Michigan, 2002.

Burgess, David F. (1990), "Services as Intermediate Goods: The Issue of Trade Liberalization", The Political Economy of International Trade: Essays in Honor of Robert E. Baldwin, 1990, pp.122-139, Oxford and Cambridge, MA: Blackwell.

Deardorff, Alan V. (2000), "International Provision of Trade Services, Trade, and Fragmentation" Discussion Paper No. 463. Research Seminar in International Economics, University of Michigan, August 2000.

Djajic and Kierskowski. (1989), "Goods, Services and Trade”, Economica, February 1989, 56(221), pp. 83-95.

Findlay, C. and Warren, T. (eds.) 2000, "Impediments to Trade in Services: Measurement and Policy Implications, Routledge", London and New York, December.

Francois, Joseph. "Producer Services, Scale, and the Division of Labor". Oxford Economic Papers, N. S. ,October 1990, 42(4), pp.715-729.

Francois, J. \& Schuknecht, L. (1999), "Trade in Financial Services: Procompetitive Effects and Growth Performance", CEPR Discussion Papers 2144, C.E.P.R. Discussion Papers.

Harrigan, James. (1993), “OECD Imports and Trade Barriers in 1983," Journal of International Economics, (35), 91-111.

Harrigan, James. (1995a), "The Volume of Trade in Differentiated Goods: Theory and Evidence," The Review of Economics and Statistics, May 1995, (77), 283-293.

Harrigan. (1995b), "Factor Endowments and the International Location of Production: Econometric Evidence for the OECD, 1970-1985," Journal of International Economics, August 1995, 39(1/2), 123-141.

Harrigan. (1996), "Openness to Trade in Manufactures in the OECD," Journal of International Economics, February 1996, 40, 23-39.

Hirsch, Seev. (1989), "International Transactions Involving Interactions: A Conceptual Framework Combining Goods and Services", Services in World Economic Growth: Symposium 1988 (1989), pp.63-84, Tubingen, West Germany: Mohr (Siebeck); Boulder, Colo. and London: Westview Press.

Hoekman, Bernard and Primo Braga Carlos A. (1997), "Protection and Trade in Services: A Survey," Open Economies Review, 8(3), pp.285-308. 
Ishikawa, Jota. (1992), "Trade Patterns and Gains from Trade with an Intermediate Good Produced under Increasing Returns to Scale”, Journal of International Economics, 32 (1-2), pp.57-81.

Jones,Ronald W. and Kierzkowski, Henryk. (1990),"The Role of Services in Production and International Trade: A Theoretical Framework," The Political Economy of International Trade: Essays in Honor of Robert E. Baldwin, pp.31-48, Oxford and Cambridge, Mass: Blackwell 1990.

Jones, Ronald W. and Ruane, Frances. (1990), "Appraising the Options for International Trade in Services", Oxford Economic Papers, N. S., 42(4), pp.672-687.

Kellenberg D. (2005), "An Empirical Assessment of Infrastructures, Trade Cost vs. Productivity Effects in International Trade", mimeo.

Mazumdar J. and Nair-Reichert U. (2005), "A Model of Service Trade and Export Competitiveness," mimeo.

Markusen, James R. (1983), "Factor Movements and Commodity Trade as Complements", Journal of International Economics, 14(3-4), pp.341-356.

Markusen, James R. (1989), "Trade in Producer Services and in Other Specialized Intermediate Inputs". The American Economic Review, March, pp.85-95.

Markusen and Svennson. (1985), "Trade in Good and Factors with International Differences in Technology", International Economic Review, 26(2), 175-191.

Markusen, James R. et al. (2000), "The Theory of Endowment, Intra-industry and Multinational Trade". Journal of International Economics, 52(2), pp.209-234.

Marrewijk, Stibora, Vaal and Viaene. (1997), "Producer Services, Comparative Advantage, and International Trade Patterns". Journal of International Economics, 42, pp.195220.

Marrewijk, Stibora and Vaal. (1996), "Services Tradability, Trade Liberalization and Foreign Direct Investment", Econometrica, 63, pp.611-631.

Mattoo, A., R. Rathindran and A. Subramaniam. (2001), "Measuring Services Trade Liberalization and its Impact on Trade Growth: An Illustration," World Bank Working Paper 2655.

Melvin, James R. (1989), “Trade in Producer Services: A Heckscher-Ohlin Approach". Journal of Political Economy, 97(5), pp.1180-1196.

OECD (2002), "GATS: The Case for Opens Services Market."

Mundell, R. (1957), "International Trade and Factor Mobility," American Economic Review, 47, pp 321-335.

Robinson, S., Z. Wang and W. Martin. (2002), "Capturing the Implications of Services Trade Liberalization," Economic Systems Research, 14(1).

Svennson, L. (1984), "Factor Trade and Goods Trade," Journal of International Economics, 16, 365-378.

Whalley, John. (2003), "Assessing the Benefits to Developing Countries of Liberalization in Service Trade," NBER Working Paper 10181. 


\section{Appendix}

\section{A. Data sources}

- Service Trade: Bureau of Economic Analysis; the definitions of the various services are in Appendix 2.

- Merchandise Trade: UN Trade Statistics compiled by Statistics Canada.

- Capital: Investment data from the Penn World Table was used to construct capital stock measures using a perpetual inventory method.

- Labor (High Skilled, Medium Skilled and Unskilled): Data on the fraction of the adult population that have attained primary, secondary and tertiary education were available from the Barro and Lee education dataset. These ratios were applied to the working age population data available from the Penn World Table to obtain estimates of the three kinds of labor.

- Land: World Development Indicators.

- Gross Domestic Product (GDP), Service sector share of GDP of trading partners: World Development Indicators

- Trade Share of GDP: World Development Indicators

- Investment cost index: Kellenberg (2005). It ranges from 0-100 with higher values indicating higher costs of investing in that country.

- Gravity Variables: http://www.freit.org/TradeResources/TradeData.html\# Gravity

- Language: US trade partners with English as their language.

- Contiguity: Countries that share a common border with the US.

- Distance: the Great Circle distance between capital cities.

\section{B. Services definitions}

Business and professional services include advertising, computer services, database and other information services; research, development, and testing services; management, consulting; legal services; construction, engineering, architectural, and mining services; industrial engineering services; installation, maintenance, and repair of equipment; and other services.

Financial service exports include brokerage services, underwriting services, credit related services, financial management services, financial advisory and custody services, securities lending services and foreign exchange brokerage services.

Telecommunication services include message telecom services, private leased 
channel services, telex and telegram services, value added or enhanced services such as electronic mail and support services such as maintenance and repair of telecommunication equipment etc. 